Gut, 1982, 23, 475-480

\title{
Serum and intestinal secretory IgA in alcoholic cirrhosis of the liver
}

\author{
G PELlETIER, M J BRIANTAIS, C BUFFET, \\ $J$ PILLOT, and $J$ P ETIENNE
}

From the Liver and Gastrointestinal Diseases Service, Hôpital Bicètre, Kremlin-Bicètre, and the Department of Immunology and Bacteriology and Microbial Immunology Unit, Institut Pasteur, Paris, France

SUMmaRY Serum and intestinal secretory $\operatorname{IgA}(\operatorname{sg} A)$ were investigated in control subjects and patients with alcoholic cirrhosis of the liver. Intestinal secretions were sampled by intraluminal perfusion with a balloon catheter. Monomeric IgA and $\operatorname{sIgA}$ were assayed by reversed radial immunodiffusion and nephelometry after separation by Ultrogel column filtration. High levels of serum sIgA were found only in patients with severe cirrhosis accompanied by jaundice. The intestinal rate of secretion of $\operatorname{sIgA}$ measured in these patients was significantly lower than that observed in either the controls or the patients with compensated cirrhosis. Such an intestinal sIgA deficiency, which could be explained either by a fall in small intestinal immunocyte synthesis or by a defect in the transenterocyte transport system, could be partially responsible for the high incidence of intestinal infection observed in severe cirrhosis.

The presence of secretory $\operatorname{IgA}(\operatorname{sig} A)$ in human serum is well documented. ${ }^{1-3}$ Liver diseases, notably alcoholic cirrhosis of the liver, are associated with abnormally high amounts of $\operatorname{sg} \mathrm{A}$ in serum. ${ }^{4-6}$ In these cases, the observed structure of serum $\operatorname{sIgA}$ is identical with that of the $\operatorname{sIgA}$ found in external secretions. ${ }^{7}$ Apart from hypogammaglobulinaemia, the secretory component has never been detected free in serum; it has rather always been detected as covalently linked to dimeric IgA. ${ }^{137}$ Reports of small intestine involvement in cirrhosis ${ }^{8}$ decided us to undertake a parallel study of $\operatorname{sIgA}$ in serum and intestinal secretions in normal and cirrhotic subjects.

\section{Methods}

PATIENTS

These investigations were performed on three healthy subjects and six patients with alcoholic cirrhosis, three of whom presented serious signs of disease with jaundice (corresponding to Child's type C), ${ }^{9}$ while, in the other three, cirrhosis was compensated (Child's type A or B). The diagnosis of cirrhosis in each case was made on the basis of clinical and histological criteria and laboratory results. None of the subjects studied had received

Received for publication 26 October 1981 antibiotics, steroids, or potassium chloride during the preceding month and none presented obvious intestinal infection.

\section{PROCEDURE \\ Evaluation of serum $\operatorname{sig} A$}

As it is well established that the secretory component is never found free in sera apart from in hypogammaglobulinaemia, ${ }^{7}$ it is possible to evaluate the amount of $\operatorname{sIgA}$ with anti-secretory component immune serum. Therefore serum SIgA was detected and measured by radial immunodiffusion in $0.6 \%$ Agarose, using an anti-secretory component antiserum. ${ }^{10}$ The results are semi-quantitative: normal sera contain: $12.1 \mu \mathrm{g} / \mathrm{ml} \pm 6.5 \mathrm{sIgA}$; levels higher than mean value \pm 2 SD $(30 \mu \mathrm{g} \operatorname{sIgA} / \mathrm{ml})$ are considered pathological. For certain serum specimens, in particular for those with a pathological sIgA level, a semi-quantitative assay was performed by haemagglutination inhibition. ${ }^{10}$

\section{Sampling of intestinal secretions}

Intestinal secretions were sampled by intraluminal perfusion with a balloon catheter. ${ }^{11}$ The occlusive balloon was placed near the duodenojejunal junction and its position checked radiologically. Effective occlusion was confirmed both by inspection of the liquid collected at the sampling point and by injecting bromesulphonephthalein proximal to the balloon and testing its appearance at 
the sampling point. The segment explored extended from the balloon to point $40 \mathrm{~cm}$ distal to it. A SCOP PS 20 pump was used for perfusion at a constant rate of about $10 \mathrm{ml} / \mathrm{mn}(9.52-11.05 \mathrm{ml} / \mathrm{mn})$. The tracer used was polyethyleneglycol (PEG) 4000 , diluted at a concentration of $10 \mathrm{~g} / \mathrm{l}$ in physiological saline solution and detected by Hyden's method. ${ }^{12}$

The flow rate (D) of a given substance (S) is given by the formula:

$$
\mathrm{DS}=\mathrm{V} 1\left(\mathrm{~S} 1-\mathrm{S} 2 \times \frac{\mathrm{PEG} 1}{\mathrm{PEG} 2}\right),
$$

in which $\mathrm{V} 1$ is the perfusion rate, $\mathrm{S} 1$ and $\mathrm{S} 2$ the concentrations of $S$ at the perfusion and sampling points (here, $S 1=0$ ), and PEG1 and PEG2 the tracer concentrations at these points.

In order to reach equilibrium, samples were taken only after one hour and secreted jejunal fluid was collected for one hour. The samples were stored at $-20^{\circ} \mathrm{C}$ after the enzymatic inhibitor diisopropylfluorophosphate (DFP) had been added. Freezing at $-20^{\circ} \mathrm{C}$ and the addition of DFP were confirmed to have no effect on the 7SIgA and $\operatorname{sIgA}$ levels measured.

Separation and detection of $\operatorname{Ig} A$ intestinal juice The jejunal juice was concentrated 20 to 50 times and then dialysed against phosphate buffered saline.

Monomeric $\operatorname{IgA}$ (7S IgA) was separated from polymeric IgA by gel filtration: a $0.6 \mathrm{ml}$ sample of concentrate was applied to a $1.6 \times 100 \mathrm{~cm}$ column (Pharmacia) of ACA 34 Ultrogel (IBF) at a flow rate of $4.4 \mathrm{ml} / \mathrm{h}$. An example of the optical density of the eluted proteins is given in Fig. 1.

The $\operatorname{IgA}$ in the unconcentrated jejunal juice and its eluates was assayed without prior concentration by two techniques. The first employed nephelo- metry (using an immuneph B device, Immuno) with an anti- $\alpha$ chain serum. The elution positions of $11 \mathrm{~S}$ and $7 \mathrm{~S} \operatorname{IgA}$ were constant (with $\mathrm{Ve} / \mathrm{Vo}$ ratios of 1.21 and 1.53 respectively). The fractions containing the 11S IgA were entirely distinct from those containing the 7S IgA. For a given jejunal juice sample, the relative proportions of $7 \mathrm{~S} \operatorname{IgA}$ and $11 \mathrm{~S} \operatorname{IgA}$ were calculated by comparing the surface areas under the peaks obtained by the nephelometric assay.

The second assay method that was used was reversed radial immunodiffusion, for which the jejunal juice was incorporated into an agarose support, with the anti- $\alpha$ chain immune serum (CDTS Bois Guillaume), used in dilutions of $1 / 1$, $1 / 2,1 / 4$, and $1 / 8$, placed in wells from which it was allowed to migrate by diffusion. The IgA level was measured in relation to that of a human serum containing a known amount of $\operatorname{IgA}$. This procedure has been shown to underestimate the $11 \mathrm{~S}$ IgA level by a factor close to $2 .^{13}$

These two techniques were found to yield identical results (Fig. 2).

Serum albumin and jejunal liquid albumin levels These were determined by radial immunodiffusion (Institut Pasteur production: Protéïplaques).

\section{Statistical analysis}

Analysis of the results was performed by the Mann-Whitney U test. All significance levels quoted are one-tailed.

\section{Results}

\section{SERUM SIGA}

Determined by radial immunodiffusion

The amounts measured in the three controls were

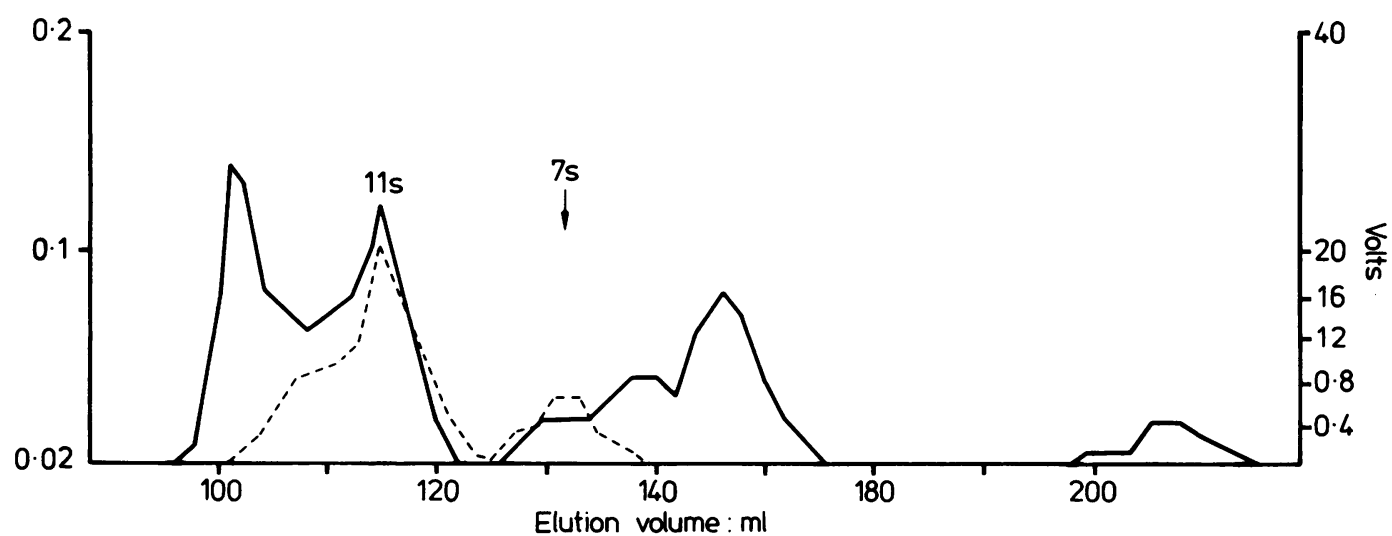

Fig. 1 Example of fractionation of jejunal juice on ACA 34 Ultrogel. — Optical density of eluted proteins. -.-. IgA amounts determined by nephelometry. 


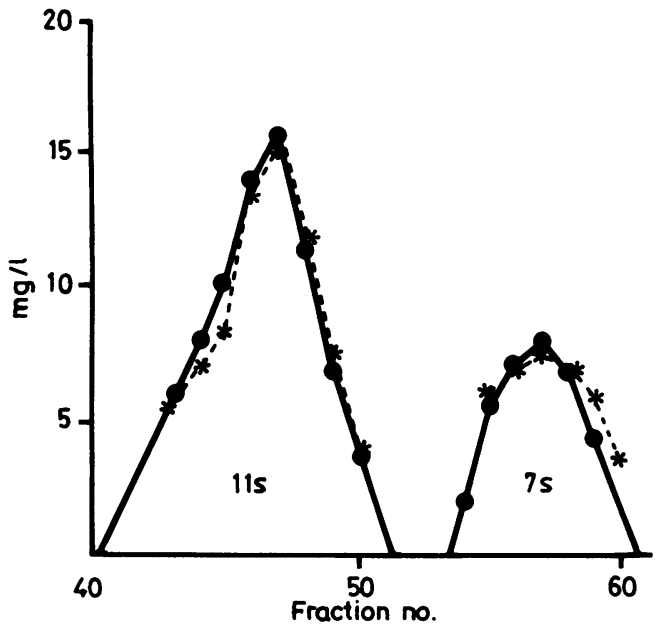

Fig. 2 Example of fractionation of jejunal juice on $A C A$ 34 Ultrogel. IgA assays in the eluted fractions, obtained by nephelometry (-) or inverse radial immunodiffusion (--.).

normal (less than $30 \mu \mathrm{g} / \mathrm{ml}$ ). In the compensated cirrhosis patients, the serum $\operatorname{sIgA}$ levels were also found to be normal. In the patients with severe cirrhosis, the serum $\operatorname{sIgA}$ levels were high $(>30$ $\mu \mathrm{g} / \mathrm{ml})$.

\section{Determined by haemagglutination inhibition}

The results are shown in Table 1 . The patients with severe cirrhosis were found to have serum $\operatorname{sIgA}$ levels close to 85,104 , and $140 \mu \mathrm{g} / \mathrm{ml}$.

PROPORTIONS OF 7S IGA AND 11S IGA IN JEJUNAL LIQUID (Table 2)

In the controls $11 \mathrm{~S} \operatorname{IgA}$ was found to constitute $89-92 \%$ of the total jejunal $\operatorname{IgA}$. In compensated cirrhosis, this proportion was $84-92 \%$, while in severe cirrhosis, the proportion observed was 59$69 \%$.

JEJUNAL FLOW RATE OF SECRETION OF 7S IGA AND 11s IGA (Table 1)

The jejunal rate of secretion of $7 \mathrm{~S} \operatorname{IgA}$ was found to be comparable in all three groups: $78.3 \mu \mathrm{g} / \mathrm{mn}$ (median) in the controls, 61.7 in compensated cirrhosis, and 102.7 in severe cirrhosis.

On the other hand, the rate of secretion of $\operatorname{sIgA}$ observed in the patients with severe cirrhosis $(200 \cdot 1$ $\mu \mathrm{g} / \mathrm{mn})$ (median) was significantly lower $(\mathrm{p}<0.05)$ than that measured either in the controls $(793.8)$ or in the patients with compensated cirrhosis $(620 \cdot 3)$.
Table 1 Serum sIgA levels

\begin{tabular}{lll}
\hline $\begin{array}{l}\text { Medical state } \\
\text { of subjects }\end{array}$ & $\begin{array}{l}\text { Radial } \\
\text { immunodiffusion* } \\
(\mu \mathrm{g} / \mathrm{ml})\end{array}$ & $\begin{array}{l}\text { Haemagglutination } \\
\text { inhibition } \\
(\mu \mathrm{g} / \mathrm{ml})\end{array}$ \\
\hline Control & - & $\mathrm{ND} \dagger$ \\
Control & - & 28 \\
Control & - & 26 \\
Compensated cirrhosis & - & $\mathrm{ND} \dagger$ \\
Compensated cirrhosis & - & $\mathrm{ND} \dagger$ \\
Compensated cirrhosis & - & 24 \\
Severe cirrhosis & + & 85 \\
Severe cirrhosis & + & 104 \\
Severe cirrhosis & + & 140 \\
\hline$*-=<30 \mu \mathrm{g} / \mathrm{ml} ;+=>30 \mu \mathrm{g} / \mathrm{ml}$. & \\
+ Not done. & &
\end{tabular}

JEJUNAL ALBUMIN RATE OF SECRETION

This was always found to be within the normal range, thus excluding the possibility of associated exudative enteropathy (Table 3 ).

\section{Discussion}

The quantitative study of intestinal sIgA levels involves two methodological problems: sampling of the intestinal juice and measurement of $\operatorname{sIgA}$ in a mixture containing monomeric and polymeric $\operatorname{IgA}$.

Samples obtained by ordinary intestinal suction, with levels expressed in terms of concentration, are difficult to interpret,${ }^{14}$ as the intestinal juice is mixed with salivary, gastric, biliary, and pancreatic secretions including proteolytic enzymes, and its degree of dilution depends on the state of absorption or secretion of the intestine. The technique of intestinal perfusion with an occlusive balloon ${ }^{11}$ avoids these causes of error by blocking proximal secretions and yielding results in terms of

Table 2 Relative proportions of $7 S$ and $11 S \operatorname{IgA}$ in jejunal juice and jejunal IgA rates of secretion

\begin{tabular}{|c|c|c|c|}
\hline $\begin{array}{l}\text { Medical state } \\
\text { of subjects }\end{array}$ & $\begin{array}{l}\text { Percentage } \\
\text { of } 11 S \text { IgA } \\
\text { in jejunal } \\
\text { juice }\end{array}$ & $\begin{array}{l}\text { Jejunal } \\
\text { rate of } \\
\text { secretion } \\
7 S \mathrm{IgA}\end{array}$ & $\begin{array}{l}11 S \mathrm{IgA} \\
(\mu \mathrm{g} / \mathrm{min} / 40 \mathrm{~cm} \\
\text { jejunum })\end{array}$ \\
\hline 1 Control & 84 & $160 \cdot 7$ & $845 \cdot 2$ \\
\hline 2 Control & 92 & $54 \cdot 5$ & $634 \cdot 5$ \\
\hline 3 Control & 91 & $78 \cdot 3$ & $793 \cdot 8$ \\
\hline 4 Compensated & & & \\
\hline 5 cirrhosis & 92 & $54 \cdot 2$ & $620 \cdot 3$ \\
\hline cirrhosis & 89 & $61 \cdot 7$ & $502 \cdot 4$ \\
\hline $\begin{array}{l}6 \text { Compensated } \\
\text { cirrhosis }\end{array}$ & 78 & $189 \cdot 6$ & 674 \\
\hline 7 Severe cirrhosis & 59 & $145 \cdot 5$ & $209 \cdot 7$ \\
\hline 8 Severe cirrhosis & 66 & $102 \cdot 7$ & $200 \cdot 1$ \\
\hline 9 Severe cirrhosis & 69 & $72 \cdot 4$ & 160 \\
\hline
\end{tabular}


Table 3 Serum albumin and jejunal albumin rates of secretion

\begin{tabular}{|c|c|c|}
\hline $\begin{array}{l}\text { Medical state } \\
\text { of subjects }\end{array}$ & $\begin{array}{l}\text { Serum } \\
\text { albumin } \\
(\mathrm{g} / \mathrm{l})\end{array}$ & $\begin{array}{l}\text { Jejunal } \\
\text { albumin rate of } \\
\text { secretion } \\
\text { ( } \mu \text { g/min } 140 \mathrm{~cm} \\
\text { jejunum) }\end{array}$ \\
\hline 1 Control & 35 & $316 \cdot 5$ \\
\hline 2 Control & $44 \cdot 5$ & $79 \cdot 5$ \\
\hline 3 Control & $36 \cdot 8$ & 35 \\
\hline 4 Compensated cirrhosis & $39 \cdot 5$ & 21 \\
\hline 5 Compensated cirrhosis & 47 & 157 \\
\hline 6 Compensated cirrhosis & 30 & 338 \\
\hline 7 Severe cirrhosis & $28 \cdot 6$ & 428 \\
\hline 8 Severe cirrhosis & 24 & $193 \cdot 1$ \\
\hline 9 Severe cirrhosis & $31 \cdot 4$ & 84 \\
\hline
\end{tabular}

flow rates. Rambaud $e t$ al ${ }^{15}$ have demonstrated the validity of this method, the results of which are not influenced by the presence of the balloon, by the flow rate, or by transintestinal absorption/secretion.

As far as the assay of $\operatorname{IgA}$ in a mixture of monomeric and polymeric IgA is concerned, the usual immunological techniques, using radial immunodiffusion in agarose and $7 \mathrm{~S}$ or $11 \mathrm{~S}$ standard samples, are unsatisfactory, as the $7 \mathrm{~S}$ scale underestimates the $\operatorname{IgA}$ level, ${ }^{16}$ while the $11 \mathrm{~S}$ one overestimates it. ${ }^{17}$ Duprey et al ${ }^{13}$ have shown that reversed radial diffusion yields a valid estimate of $7 \mathrm{~S}$ and $11 \mathrm{~S} \operatorname{IgA}$ if the latter is corrected by a factor of about 2. We obtained identical results by nephelometry. The relative proportions of the two types of IgA were ascertained by column gel filtration. Intestinal $11 \mathrm{~S} \operatorname{IgA}$ is virtually entirely $\operatorname{sIgA.} .^{18}$

Serum $\operatorname{sIgA}$ is known to be raised in cirrhosis. ${ }^{4-6}$ We found this rise in three cases of severe cirrhosis with jaundice. On the other hand, the serum $\operatorname{sigA}$ level was observed to be normal in the three cases of compensated cirrhosis, none of which was associated with jaundice. The presence or absence of cholestasis in these two groups of patients may in part explain this difference. In this connection, it was shown recently that experimentally produced bile duct obstruction in rats produced a rapid and considerable increase in the serum $\operatorname{sig} \mathrm{A}$ level. ${ }^{19} \mathrm{~A}$ similar process can be observed in human liver disease: the highest serum sIgA levels are seen when cholestasis is present (unpublished data). Another study $^{20}$ demonstrated the role of the secretory component in the active and selective transport of dimeric serum IgA into the bile; Nagura et al suggest that the cellular pathway for entry of polymeric $\operatorname{IgA}$ into the bile is an endocytic transport across biliary epithelium mediated by secretory component. ${ }^{21}$

The proportion of $\operatorname{sg} \mathrm{A}$ relative to total $\operatorname{IgA}$ in the jejunal juice as measured in our control subjects (about 90\%) is in agreement with Tomasi's results. ${ }^{18}$ Other authors have found figures of $70 \%{ }^{16}$ or from 64 to $80 \%$. $^{13}$

The possibility of associated exudative enteropathy, a possible finding in cirrhosis, and one which can modify the IgA rate of secretion, was eliminated by measuring the rate of secretion of jejunal albumin; this was shown to be within the normal range, as defined by Nouel, ${ }^{22}$ in both the controls and the cirrhotic patients.

As far as we know, no studies of the intestinal rate of secretion of $\operatorname{sIgA}$ and $7 \mathrm{~S} \operatorname{IgA}$ in normal or cirrhotic subjects have been published. Our results demonstrate a decrease in the jejunal $\operatorname{sIgA}$ rate of secretion in severe cirrhosis. Of course, only a small number of cases could be explored, but the results are homogeneous and the difference between this rate of secretion and that observed in the controls and the cases of compensated cirrhosis is significant $(p<0.05)$. On the other hand, the intestinal secretion of 7S $\operatorname{IgA}$ was found to be identical in all nine subjects. Although for such small groups the statistical risk $\beta$ of incorrectly concluding that there is no difference among them is high, it can at least be said that the mean values observed in the three groups are extremely close. It must be noted that the mechanisms responsible for the secretion of $7 \mathrm{~S} \operatorname{IgA}$ and $\operatorname{sIgA}$ are not the same: the former occurs by a passive and non-specific process ${ }^{23}{ }^{24}$ whereas, in the latter, a specific system exists for the transport of the dimeric immunoglobulins across the crypt enterocytes by the secretory component. ${ }^{23} 25-27$

Several hypotheses can be proposed to explain the deficit in intestinal $\operatorname{sIgA}$ in severe cirrhosis with jaundice:

1 A cholestasis-induced deficiency in $\operatorname{sIg} \mathrm{A}$ of biliary origin cannot be maintained, as the occlusive balloon technique of intestinal perfusion prevents inclusion of bile secretions in the samples.

2 Decreased $\operatorname{sIgA}$ synthesis by digestive system immunocytes could be implied, but this possibility was not explored in our study as coagulation disorders in our cases of severe cirrhosis made intestinal biopsy impossible. In this connection, it can be mentioned that a decrease in intestinal submucosal immunocytes, particularly $\operatorname{IgA}$ immunocytes, has been reported in cirrhosis. ${ }^{8}$

3 Impaired transport of dimeric $\operatorname{IgA}$ across the enterocytes by the secretory component is a possibility, as $7 \mathrm{~S} \operatorname{IgA}$ secretion, which occurs by simple diffusion, remains normal. The dimeric IgA secreted by the small intestine immunocytes would then enter the general circulation rather than the intestinal lumen. This hypothesis is supported by Brandtzaeg and Baklien's report ${ }^{28}$ of an adolescent with very pronounced polyclonal IgA hyper- 
secretion in which an excessive population of small intestine $\operatorname{IgA}$ immunocytes was observed. This hypersecretion was seen to produce a considerable increase in serum $\operatorname{IgA}$, while the $\operatorname{sIgA}$ in the intestinal secretions (sampled by ordinary intestinal suction) remained normal. Such a finding implies a defect in the secretory component transport system or its saturation.

Furthermore, $\mathrm{F}$ and $\mathrm{C}$ André ${ }^{5}$ have shown that the considerable increase in serum $\operatorname{IgA}$ seen in cirrhosis is due in large part to a rise in dimeric $\operatorname{IgA}$, the concentration of which was found to be about seven times higher than normal. This implies that some of the dimeric $\operatorname{IgA}$ which is accumulated in the serum may arise from that secreted by the intestinal immunocytes which is neither secreted as $\operatorname{sIgA}$ into the intestinal liquid nor secreted into the bile.

4 The $\operatorname{sig} A$ secreted into the intestine could be reabsorbed by the altered mucosa, but this possibility is unlikely, as it was shown that the uptake of dimeric IgA from the intestine into the serum is inhibited by the presence of secretory component on IgA. ${ }^{29}$

The lowered intestinal sIgA level observed in our cases of severe cirrhosis may lead to a defective small intestinal defence system and hence be partially responsible for the increased incidence of infection-diarrhoea, septicaemia of digestive origin, or of infected ascites that is observed in such patients.

We wish to thank Professor J C Rambaud and Dr F Duprey for their helpful advice.

\section{References}

1 Thompson RA, Asquith P, Cooke WT. Secretory IgA in the serum. Lancet 1969; 2: 517-9.

2 Waldman RH, Mach JP, Stella MM, Rowe DS. Secretory IgA in human serum. J Immunol 1970; 105: 43-7.

3 Brandtzaeg P. Occurrence of secretory piece in human serum. J Immunol 1971; 106: 318-23.

4 Thompson RA, Carter R, Stokes RP, Geddes AM, Goodall JAD. Serum immunoglobulins, complement component levels and auto-antibodies in liver diseases. Clin Exp Immunol 1973; 14: 335-46.

5 André F, André C. Participation de l'Immunoglobuline A monomérique et dimérique à l'hypergammaglobulinémie de la cirrhose éthylique. Biol Gastroenterol 1976; 9: 147-50.

6 Iscaki S, Buffet C. Secretory IgA increase in sera of patients with liver diseases. La Ricerca Clin Lab 1978; 8: 287-91.
7 Iscaki S, Geneste C, Pillot J. Molecular state of secretory component in human sera. Immunol Letters 1980; 1: 217-21.

8 Dubrisay J, Demelier JF, Barbier JPH, Renault P, Carnot F, Debetz J, Dadoume JP. Cirrhose du foie et intestin grêle. Confrontations cliniques, biologiques, histologiques, immunologiques et bactériologiques. Sem Hôp Paris 1973; 49: 1639-48.

9 Child G. The liver and portal hypertension. Philadelphia: Saunders, 1964: 50.

10 Iscaki S, Geneste C, D'Asambuja S, Pillot J. Human secretory component in human sera. J Immunol Methods 1979; 28: 331-9.

11 Modigliani R, Rambaud JC, Bernier JJ. The method of intraluminal perfusion of the human small intestine. Digestion 1973; 9: 176-92.

12 Hyden S. A turbidimetric method for the determination of the higher polyethylene glycols in biological materials. Ann R Agr Coll 1955; 22: 139-45.

13 Duprey F, Delpech B, Rambaud JC. Méthode de dosage de l'IgA 7S et de l'IgA 11S dans le perfusat de la lumière jéjunale de l'homme. Gastroenterol Clin Biol 1979; 3: 79-80.

14 Brandtzaeg P, Fjellanger I, Gjeruldsen ST. Human secretory immunoglobulins. I. Salivary secretions from individuals with normal or low levels of serum immunoglobulins. Scand J Haematol 1970; suppl 12: 54-6.

15 Rambaud JC, Duprey F, Nouel O. Étude méthodologique de la détermination par perfusion segmentaire des débits secrétoires d'IgA dans la lumière jéjunale de l'homme. Gastroenterol Clin Biol 1979; 3: 89.

16 Bull DM, Bienenstock J, Tomasi TB. Studies on human intestinal immunoglobulin A. Gastroenterology 1971; 60: 370-80.

17 Samson RR, Clelland PBL, Shearmann DJC. Studies on the quantitation of immunoglobulin in human intestinal section. Gut 1973; 14: 616-26.

18 Tomasi TB. Secretory immunoglobulins. $N$ Engl J Med 1972; 287: 500-6.

19 Lemaitre-Coelho I, Jackson GDF, Vaerman JP. High levels of secretory IgA and free secretory component in the serum of rats with bile duct obstruction. J Exp Med 1978; 147: 934-9.

20 Fisher M, Nagy B, Bazin H, Underdown BJ. Biliary transport of IgA: role of secretory component. Proc Natl Acad Sci USA 1979; 76: 2008-12.

21 Nagura H, Smith PD, Nakane PK, Brown WR. IgA in human bile and liver. J Immunol 1981; 126: 587-95.

22 Nouel O. Étude méthodologique de la détermination par perfusion segmentaire des débits de sérum, d'albumine et d'immunoglobuline A secrétés dans la lumière jéjunale. Université Paris VI: Thesis, 1976.

23 Brandtzaeg P, Baklien $\mathrm{K}$. Intestinal secretion of $\operatorname{IgA}$ and IgM: a hypothetical model. Immunology of the gut. Ciba Foundation Symposium 1977; 46: 77-113.

24 Walker WA, Isselbacher KJ. Intestinal antibodies. $N$ Engl J Med 1977; 297: 767-73.

25 Brown WR, Isobe K, Nakane P, Pacini B. Studies on translocation of immunoglobulins across intestinal epithelium: evidence for binding of $\operatorname{IgA}$ and $\operatorname{IgM}$ to secretory component in intestinal epithelium. Gastroenterology 1977; 73: 1333-9. 
26 Brandtzaeg P. Mucosal and glandular distribution of immunoglobulin components: differential localization of free and bound SC in secretory epitheliums cells. $J$ Immunol 1974; 112: 1553-9.

27 Brandtzaeg P. Polymeric IgA is complexed with secretory component (SC) on the surface of human intestinal epithelial cells. Scand J Immunol 1978; 8: 39-52.
28 Brandtzaeg P, Baklien K. Characterization of the IgA immunocyte population and its product in a patient with excessive intestinal formation of IgA. Clin Exp Immunol 1977; 30: 77-88.

29 David PJ, Porter P. A mechanism for secretory IgA mediated inhibition of the cell penetration and intracellular development of Eimeria terella. Immunology 1979; 36: 471-7. 